\title{
Complete Blood Count from Clinical Peripheral Blood (Within 24 Hours of Banking)
}

National Cancer Institute

\section{Source}

National Cancer Institute. Complete Blood Count from Clinical Peripheral Blood (Within

24 Hours of Banking). NCl Thesaurus. Code C158881.

A section header for lab results related to a complete blood count from clinical peripheral blood obtained within 24 hours of banking. 